Kraft, R. O., Fry, W. J., Wilhelm, K. G., and Ransom, H. K. (1967). Archives of Surgery, 95, 625.

Macdonald, J. M., Webster, M. M., Tennyson, C. H., and Drapanas, T. (1969). American fournal of Surgery, 117, 204.

Reichle, F. A., et al. (1971). Archives of Surgery, 104, 133.

Sawyers, J. L., Scott, H. W., Edwards, W. H., Schulle, H. J., and Law, D. H.

(1968). American fournal of Surgery, 115, 165.
Silver, D., Porter, J. M., Acinapura, A. J., and McGregor, F. H. (1966). Monographs in the Surgical Sciences, 3, 365.

Thomas, J. E. (1957). Physiological Reviews, 37, 453.

Tovey, F. I. (1969). British fournal of Surgery, 56, 281.

Wilkinson, A. R., and Johnston, D. (1972). Paper presented to Surgical Research Society, London Meeting, January, 1972.

\title{
Vagotomy Without Diarrhoea
}

\author{
D. JOHNSTON, \\ C. S. HUMPHREY, \\ B. E. WALKER, \\ C. N. PULVERTAFT, J. C. GOLIGHER
}

British Medical fournal, 1972, 3, 788-790

\section{Summary}

The incidence of diarrhoea after three types of vagotomy was assessed "blind" at a gastric follow-up clinic one year after operation. Diarrhoea was recorded in $24 \%$ of patients after truncal vagotomy and pyloroplasty, in $18 \%$ after selective vagotomy and pyloroplasty, but in only $2 \%$ of patients after highly selective vagotomy without a drainage procedure. The incidence of diarrhoea was significantly less $(P<0.01)$ after highly selective vagotomy than after either of the other procedures.

Hypertonic glucose solution given by mouth to 15 representative patients from each group and to 15 patients before operation provoked the onset of diarrhoea in $67 \%$ of the patients who had undergone truncal vagotomy and pyloroplasty, in $60 \%$ of those who had undergone selective vagotomy and pyloroplasty, in $13 \%$ of those who had undergone highly selective vagotomy without a drainage procedure, and in none of the preoperative patients. Again the difference between the "highly selective" group and the other two groups of vagotomized patients was statistically significant.

It is suggested that postvagotomy diarrhoea is attributable both to unregulated gastric emptying after truncal or selective vagotomy with a drainage procedure and to the extragastric denervation produced by truncal vagotomy. "Postvagotomy" diarrhoea can be virtually eliminated by using highly selective vagotomy without a drainage procedure.

\section{Introduction}

About $25 \%$ of patients experience episodic diarrhoea after truncal vagotomy with a drainage procedure for duodenal ulcer (Table I). The diarrhoea is usually quite mild, but in 2 or $3 \%$ it is so severe that in spite of relief from ulcer pain the patient believes that the operation has failed. The cause of the diarrhoea is not known and it can be very difficult to treat. The incidence of diarrhoea is significantly less after bilateral selective vagotomy (Kennedy and Connell, 1970) (Table I), in which the vagal nerve supply to the pancreas, biliary tract, and small intestine is preserved, but the incidence of around $12 \%$ is appreciable and a few patients still suffer severely. A different explanation

\footnotetext{
University Department of Surgery and Gastric Follow-Up Clinic, General Infirmary at Leeds

D. JOHNSTON, F.R.C.S., Reader in Surgery

C. S. HUMPHREY, M.B., CH.B., Research Assistant and Honorary Registrar J. C. GOLIGHER, CH.M., F.R.C.S., Professor of Surgery

Gastric Follow-up Clinic, York Hospitals

C. N. PULVERTAFT, M.D., F.F.R., Director

St. James's Hospital, Leeds

B. E. WALKER, M.D., M.R.C.P., Lecturer in Medicine
}

TABLE I-Comparison of Effects of Truncal and Selective Vagotomy* on Incidence of Postvagotomy Diarrhoea

\begin{tabular}{|c|c|c|c|c|}
\hline \multirow{2}{*}{ Source } & \multicolumn{2}{|c|}{$\begin{array}{c}\text { Truncal } \\
\text { Vagotomy }\end{array}$} & \multicolumn{2}{|c|}{$\begin{array}{l}\text { Selective } \\
\text { Vagotomy }\end{array}$} \\
\hline & $\begin{array}{c}\text { No. of } \\
\text { Patients }\end{array}$ & $\begin{array}{c}\% \text { with } \\
\text { Diarrhoea }\end{array}$ & $\begin{array}{l}\text { No. of } \\
\text { Patients }\end{array}$ & $\begin{array}{c}\% \text { with } \\
\text { Diarrhoea }\end{array}$ \\
\hline 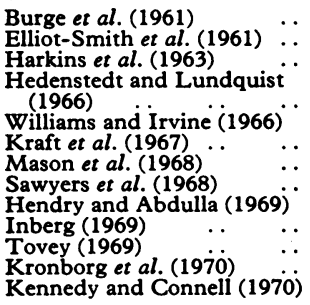 & $\begin{array}{r}100 \\
131 \\
60 \\
30 \\
43 \\
50 \\
42 \\
90 \\
300 \\
81 \\
118 \\
35 \\
50\end{array}$ & $\begin{array}{r}26 \\
2 \\
68 \\
50 \\
5 \\
9 \\
37 \\
33 \\
21 \\
23 \\
36 \\
7 \\
46 \\
30\end{array}$ & $\begin{array}{r}100 \\
44 \\
52 \\
44 \\
22 \\
50 \\
40 \\
53 \\
100 \\
101 \\
100 \\
36 \\
48\end{array}$ & $\begin{array}{r}12 \\
29 \\
29 \\
6 \\
0 \\
27 \\
20 \\
12 \\
9 \\
12 \\
99 \\
11 \\
8\end{array}$ \\
\hline Total $\ldots$ & 1,130 & $24 \cdot 6$ & 790 & $12 \cdot 3$ \\
\hline
\end{tabular}

*With pyloroplasty, gastrojejunostomy, or antrectomy. In each series the same drainage procedure or resection was used.

for the diarrhoea is suggested by the finding that the stomach is incontinent of fluids after truncal or selective vagotomy with a drainage procedure (McKelvey et al., 1969; McKelvey, 1970). Rapid gastric emptying is followed by swift passage of the liquid through the intestines, resulting in diarrhoea. Thus "postvagotomy" diarrhoea may be produced in some patients by vagal denervation of extragastric viscera, while in others destruction or bypass of the pylorus in combination with gastric vagotomy may be the principal factor.

If this hypothesis is correct the incidence of diarrhoea should be very low indeed after highly selective vagotomy, in which the vagal nerve supply to the extragastric viscera is preserved and the antropyloroduodenal segment is left completely intact (Amdrup and Jensen, 1970; Johnston and Wilkinson, 1970). We report here the results of an investigation into the bowel habits of three groups of patients one year after truncal vagotomy and pyloroplasty, selective vagotomy and pyloroplasty, and highly selective vagotomy without a drainage procedure.

\section{Patients and Methods}

The 150 patients studied had undergone elective surgery for duodenal ulcer at least one year previously in the University Department of Surgery at Leeds General Infirmary. The operative procedures used were truncal vagotomy and pyloroplasty, bilateral selective vagotomy and pyloroplasty, and highly selective vagotomy without a drainage procedure (Fig. 1). Details of bowel habit were recorded when the patients attended the gastric follow-up clinic for review one year after operation. The patients were interviewed by a panel consisting of a physician, a radiologist, and two surgeons who were unaware of the type of gastric operation which had been performed. The last 50 consecutive patients treated by each type of vagotomy and seen one year after operation were chosen for review. Although the 


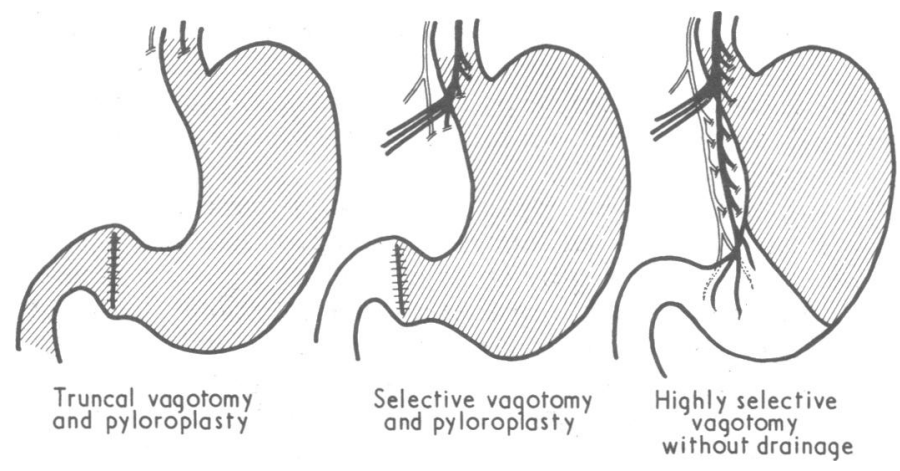

FIG. 1-The three types of vagotomy. Hatched areas represent extent of denervation.

TABLE II-Details of Patients

\begin{tabular}{|c|c|c|c|}
\hline & $\begin{array}{c}\text { Truncal } \\
\text { Vagotomy } \\
\text { and } \\
\text { Pyloroplasty } \\
(\mathbf{n}=50)\end{array}$ & $\begin{array}{l}\text { Selective } \\
\text { Vagotomy } \\
\text { and } \\
\text { Pyloroplasty } \\
(\mathbf{n}=50)\end{array}$ & $\begin{array}{l}\text { Highly } \\
\text { Selective } \\
\text { Vagotomy } \\
(\mathrm{n}=50)\end{array}$ \\
\hline 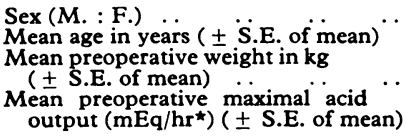 & $\begin{array}{c}42: 8 \\
44 \cdot 2 \pm 1 \cdot 6 \\
65 \cdot 3 \pm 1 \cdot 9 \\
42 \cdot 6 \pm 1 \cdot 8\end{array}$ & $\begin{array}{c}40: 10 \\
42 \cdot 8 \pm 1 \cdot 6 \\
62 \cdot 5 \pm 1 \cdot 2 \\
41 \cdot 3 \pm 1 \cdot 8\end{array}$ & $\begin{array}{c}37: 13 \\
40 \cdot 3 \pm 1 \cdot 7 \\
65 \cdot 8 \pm 1 \cdot 6 \\
42 \cdot 4 \pm 1 \cdot 9\end{array}$ \\
\hline
\end{tabular}

^Peak 20-minute acid output $\times 3$ in response to intramuscular pentagastrin $(6 \mu \mathrm{g} / \mathrm{kg})$.

operation had not been chosen at random the three consecutive series of patients were nonetheless well matched with respect to sex, age, weight, and preoperative maximal acid output (Table II).

The patient's bowel function one year after operation was recorded in detail and compared with the preoperative state. Three main categories of result were recognized: (1) no change, when bowel habit had not altered or was slightly more constipated; (2) improved, when there had been a change from constipation before operation to an easier or more frequent bowel action after operation (the motions in these patients were usually normally formed but on occasion were porridgy or soft); (3) diarrhoea, when the motions were liquid or very loose in consistency and were passed with some degree of urgency. Diarrhoea was classified as severe if the degree of urgency was so great that the patient was in danger of being incontinent or if the attacks of diarrhoea were so frequent or troublesome that they were considered by the patient to interfere greatly with his way of life. Diarrhoea was usually episodic rather than continuous in nature. Transient diarrhoea, which cleared up after the first three or four postoperative months, was ignored.

Control Studies.-A postoperative assessment of bowel habit of this type is to some extent subjective and depends on a comparison of bowel habit at the time of interview with that before operation. To obtain a better baseline for this study two control groups were also examined: firstly, 50 patients who had undergone appendicectomy, herniorrhaphy, or operation for varicose veins one year previously were asked to attend at the follow-up clinic without the previous knowledge of the interviewing panel. These patients were questioned closely on all aspects of gastrointestinal function, including bowel habit. As a second form of control detailed records of bowel habit were made in 75 patients who were admitted to the wards for surgical treatment of chronic duodenal ulcer.

Response to Test Meal of Hypertonic Glucose.-Fifteen representative patients from each group took part in an experimental attempt to provoke the onset of diarrhoea artificially by means of a test meal of hypertonic glucose solution. Particular care was taken to make the three groups representative of the larger groups with respect to clinical symptoms such as dumping and diarrhoea and to the overall Visick grading. An additional 15 patients with duodenal ulcer before operation took part in this study. After fasting overnight the patients drank $350 \mathrm{ml}$ of a $25 \%$ solution of glucose rapidly while standing upright. They remained standing for 10 minutes, then sat in a chair for the remainder of the two-hour test. Diarrhoea in the context of this test signifies the passage of a fluid motion with urgency in the course of the test. Severe diarrhoea denotes the occurrence of two or more such episodes.

\section{Results}

The overall incidence of diarrhoea after truncal vagotomy and pyloroplasty was $24 \%$, compared with $18 \%$ after selective vagotomy and pyloroplasty (Table III). Six per cent. had severe diarrhoea after truncal vagotomy compared with $2 \%$ after

TABLE III-Bowel Habit One Year after Truncal or Selective Vagotomy and Pyloroplasty or Highly Selective Vagotomy Without Drainage Procedure

\begin{tabular}{|c|c|c|c|c|c|}
\hline & & & $\begin{array}{c}\text { Truncal } \\
\text { Vagotomy } \\
\text { and } \\
\text { Pyloroplasty } \\
\text { (50 Patients) }\end{array}$ & $\begin{array}{c}\text { Selective } \\
\text { Vagotomy } \\
\text { and } \\
\text { Pyloroplasty } \\
\text { (50 Patients) }\end{array}$ & $\begin{array}{c}\text { Highly } \\
\text { Selective } \\
\text { Vagotomy } \\
\text { (50 Patients) }\end{array}$ \\
\hline $\begin{array}{ll}\text { No change } & \ldots \\
\text { Improved } & \ldots \\
\text { Diarrhoea } & \ldots \\
\text { Mild or moderate } \\
\text { Severe } & \ldots\end{array}$ & $\begin{array}{l}\because \\
\because \\
\cdots \\
\cdots\end{array}$ & $\begin{array}{l}\cdots \\
\therefore \\
\cdots \\
\cdots\end{array}$ & $\begin{array}{l}40 \% \\
36 \% \\
24 \% \\
18 \% \\
6 \%\end{array}$ & $\begin{array}{r}50 \% \\
32 \% \\
18 \% \\
16 \% \\
2 \%\end{array}$ & $\begin{array}{l}58 \% \\
40 \% \\
2 \% \\
2 \% \\
0\end{array}$ \\
\hline
\end{tabular}

The incidence of diarrhoea after highly selective vagotomy was significantly less than after truncal vagotomy and pyloroplasty $(P<0.001)$ or selective vagotomy and plyoroplasty $(\mathbf{P}<0.01)$.

selective vagotomy. These differences are not statistically significant $\left(\chi^{2}=0 \cdot 29, P>0 \cdot 6\right)$. After highly selective vagotomy only one case of mild diarrhoea was found. The incidence of $2 \%$ is significantly less than that which was recorded after truncal vagotomy $\left(\chi^{2}=10.7, P<0.001\right)$ or selective vagotomy $\left(\chi^{2}=\right.$ $7 \cdot 1, \mathrm{P}<0.01)$.

The hypertonic glucose meal produced diarrhoea in $67 \%$ of the patients after truncal vagotomy, in $60 \%$ after selective vagotomy, but in only $13 \%$ after highly selective vagotomy (Table IV). The difference between the highly selective vagotomy group and the truncal vagotomy group is statistically

TABLE IV-Number of Patients With Diarrhoea produced by Test Meal of Hypertonic (25\%) Glucose

\begin{tabular}{|c|c|c|c|c|c|}
\hline & & $\begin{array}{c}\text { Duodenal } \\
\text { Ulcer } \\
\text { before } \\
\text { operation } \\
\text { (15 Patients) }\end{array}$ & $\begin{array}{c}\text { Truncal } \\
\text { Vagotomy } \\
\text { and } \\
\text { Pyloroplasty } \\
\text { (15 Patients) }\end{array}$ & $\begin{array}{c}\text { Selective } \\
\text { Vagotomy } \\
\text { and } \\
\text { Pyloroplasty } \\
\text { (15 Patients) }\end{array}$ & $\begin{array}{c}\text { Highly } \\
\text { Selective } \\
\text { Vagotomy } \\
\text { (15 Patients) }\end{array}$ \\
\hline $\begin{array}{l}\text { Mild or moderate } \\
\text { Severe }\end{array}$ & $\because$ & $\begin{array}{l}0 \\
0\end{array}$ & $\begin{array}{l}4 \\
6\end{array}$ & $\begin{array}{l}3 \\
6\end{array}$ & 1 \\
\hline Total &.. & 0 & 10 & 9 & 2 \\
\hline
\end{tabular}

The incidence of diarrhoea after highly selective vagotomy was significantly less than after Truncal Vagotomy and Pyloroplasty $(P<0.01)$ or Selective Vagotomy and Pyloroplasty (P $<0.05)$.

significant $\left(\chi^{2}=6.81, P<0.01\right)$. The difference between the highly selective vagotomy group and the selective vagotomy group is also statistically significant $\left(\chi^{2}=4.93, P<0.05\right)$. In none of the preoperative patients with duodenal ulcer could the onset of diarrhoea be provoked by this test meal.

Of the 50 control patients whose patterns of bowei habit were recorded one year after surgery $4 \%$ had experienced occasional mild diarrhoea since operation: $92 \%$, however, were adamant that there had been no change in their bowel habit. The remaining $4 \%$ claimed an improvement in their bowel habit.

The frequency of bowei action in the 75 patients with duodenal ulcer who were questioned before operation is shown in Fig. 2. Three patients $(4 \%)$ admitted to occasional attacks of diarrhoea. Fourteen patients $(19 \%)$ reported that they were usually constipated with either infrequent or hard and painful motions. 


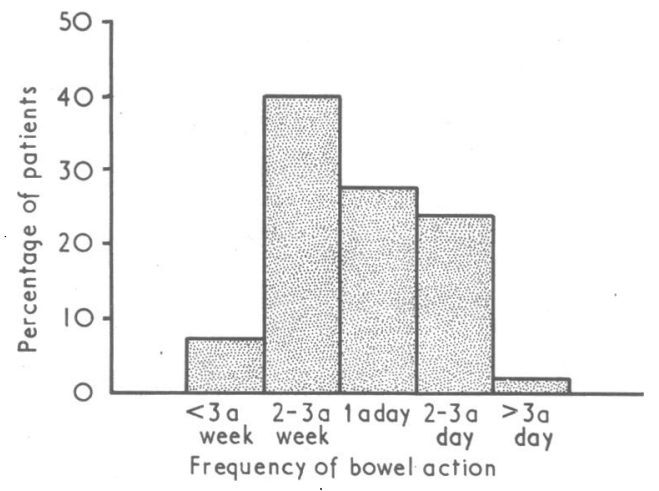

FIG. 2-Frequency of bowel action in 75 patients with duodenal ulcer before operation.

\section{Discussion}

Two major criticisms could be levelled at this study. Firstly, it might be argued that the results are invalid because the type of vagotomy used in any particular patient was not chosen at random. The patients, however, were all treated in the same surgical unit, in which the indications for operation did not change, and the assessments of bowel habit were made "blindly" by the same panel of observers at the follow-up clinic. The three groups of patients were well matched (Table II). Hence we think that the observed differences in bowel habit are directly attributable to the type of operation used rather than to dissimilarities among the groups of patients.

Secondly, it might be objected that an assessment made only one year after operation was much too early, and that different results might have been obtained from a review several years later. At the same follow-up clinic, however, the incidence of diarrhoea in 161 patients five to eight years after truncal vagotomy and pyloroplasty was $22 \%$ (Goligher et al., 1972) and in 214 patients five to eight years after truncal vagotomy and gastroenterostomy $27 \%$ (Goligher et al., 1968). Two to five years after selective vagotomy and pyloroplasty the incidence was $17 \%$ in 85 patients (unpublished data from Leeds gastric follow-up clinic) (Table V). There is little difference between these incidences and those found by us one year after operation.

TABLE v-Bowel Habit five to eight Years after Truncal Vagotomy and Pyloroplasty and two to five Years after Selective Vagotomy and Pyloroplasty

\begin{tabular}{|c|c|c|c|}
\hline & & $\begin{array}{l}\text { Truncal Vagotomy } \\
\text { and Pyloroplasty } \\
\text { (161 Patients) }\end{array}$ & $\begin{array}{l}\text { Selective Vagotomy } \\
\text { and Pyloroplasty } \\
\text { (85 Patients) }\end{array}$ \\
\hline $\begin{array}{ll}\text { No change } & \ldots \\
\text { Improved } \ldots & \ldots \\
\text { Diarrhoea } \ldots & \ldots \\
\text { Mild or moderate } \\
\text { Severe } \ldots\end{array}$ & $\begin{array}{ll}\cdots & \cdots \\
\because & \cdots \\
\cdots & \cdots \\
\cdots & \cdots\end{array}$ & $\begin{array}{r}50 \cdot 4 \% \\
27 \cdot 9 \% \\
21.7 \% \\
17 \cdot 4 \% \\
4.3 \%\end{array}$ & $\begin{array}{r}44 \cdot 7 \% \\
38 \cdot 8 \% \\
16 \cdot 5 \% \\
15 \cdot 3 \% \\
1 \cdot 2 \%\end{array}$ \\
\hline
\end{tabular}

Thus we think that the comparisons made here are valid. Altogether 150 patients have now been treated by highly selective vagotomy, the maximum period of follow-up is three and a half years, and the incidence of diarrhoea is $3 \%$. "Postvagotomy" diarrhoea appears to be due to changes in gastrointestinal physiology which are produced at the time of operation. The findings one year after surgery are unlikely to change appreciably.

These results suggest that troublesome postvagotomy diarrhoea will not occur after highly selective vagotomy. There are probably two reasons for this. Firstly, highly selective vagotomy preserves the vagal innervation of the extragastric viscera, and, secondly, by virtue of the retainea antral innervation and the absence of a drainage procedure, it also preserves a more normal pattern of gastric emptying. Nevertheless, gastric emptying is not entirely normal after highly selective vagotomy. Although postoperative changes in the direction of more rapid gastric emptying and small-bowel transit are much less pronounced after highly selective vagotomy than after truncal or selective vagotomy with a drainage procedure, such changes do still occur, particularly when the meal is of fluid or semifluid consistency (Wilkinson and Johnston, 1972; Humphrey et al., 1972). This may explain why no fewer than $42 \%$ of the 50 patients after highly selective vagotomy experienced a change in bowel habitalthough the change was for the better in $40 \%$ and for the worse in only one patient $(2 \%)$.

Those patients who reported an "improvement" in their bowel function form an interesting group. Undoubtedly their bowel habit was altered by operation, and this probably represents a definite response to altered gastrointestinal physiology rather than a subjective response to "an operation" since $92 \%$ of the control patients who had undergone non-gastric operations could not detect any change in their bowel habit.

The problem of postvagotomy diarrhoea is thus largely avoidable. It is necessary to sound a note of caution, however, for if the hepatic or coeliac nerves were to be damaged at operation the incidence of diarrhoea would undoubtedly increase. As Burge (1969) and Griffith (1969) pointed out, preservation of both these groups of vagal fibres is important in preventing postvagotomy diarrhoea. The nerves of Latarjet are of equal importance. If they should be damaged inadvertently during highly selective vagotomy the patient would have in effect an ordinary selective vagotomy without drainage, and gastric retention would probably ensue in some patients (Clarke et al., 1972). The resulting stasis and fermentation of gastric content might then give rise to diarrhoea, as happened when truncal vagotomy was performed without an added drainage procedure (Dragstedt et al., 1947).

In conclusion, we have shown that after highly selective vagotomy without a drainage procedure the incidence of diarrhoea is no higher than that in a control population, and the severe diarrhoea which afflicts a few patients after truncal or selective vagotomy with drainage is entirely absent. Whether the routine use of highly selective vagotomy is justifiable at present must still be a matter for debate, because our follow-up of 150 patients treated in this way averages a mere 20 months with a maximum of 40 months. The omens, however, seem favourable. So far there has been no operative mortality, no recurrent ulcer, and no reoperation for the relief of gastric stasis, while the overall clinical results continue to be excellent.

\section{References}

Amdrup, E., Jensen, H.-E. (1970). Gastroenterology, 59, 522

Burge, H., et al. (1961). Lancet, 2, 897.

Burge, H. (1969). In Surgery of the Stomach and Duodenum, ed. N. H. Harkins, and L. M. Nyhus, 2nd edn., p. 624. Boston, Little, Brown, and Co.

Clarke, R. J., McFarland, J. B., and Williams, J. A. (1972). British Medical Fournal, 1, 538

Dragstedt, L. R., Harper, P. V., Tovee, E. B., and Woodward, E. R. (1947). Annals of Surgery, 126, 687

Elliot-Smith, A., Painter, N. S., and Porter, R. (1961). Lancet, 2, 1036.

Goligher, J. C., et al. (1968). British Medical fournal, 2, 781

Goligher, J. C., et al. (1972). British Medical Fournal, 1, 7.

Griffith, C. A. (1969). In Surgery of the Stomach and Duodenum, ed. N. H. Harkins, and L. M. Nyhus, 2nd edn., p. 605. Boston, Little, Brown, and Co.

Harkins, H. N., et al. (1963). Annals of Surgery, 158, 448.

Hedenstedt, S., and Lundquist, G. (1966). Acta Chirurgica Scandinavica,

131, 448.
Hendry, W. G., and Abdulla, K. H. (1969). British Fournal of Surgery, 56, 1.

Humphrey, C. S., Wilkinson, A. R., and Johnston, D. (1972). Paper presented to Surgical Research Society, London Meeting, January 1972.

Inberg, M. V. (1969). Annales Chirurgiae et Gynaecologiae Fenniae, 58, Suppl. No. 165.

Johnston, D., and Wilkinson, A. R. (1970). British fournal of Surgery, 57,

Kennedy, T., and Connell, A. M. (1970). Lancet, 1, 675.

Kraft, R. O., Fry, W. J., Wilhelm, K. G., and Ransom, H. K. (1967). Archives of Surgery, 95, 625.

Kronborg, O., Malström, J., and Christiansen, P. M. (1970). Scandinavian fournal of Gastroenterology, 5, 519 .

McKelvey, S. T. D., Connell, A. M., and Kennedy, T. (1969). Gut, 10, 1047

McKelvey, S. T. D. (1970). British fournal of Surgery, 57, 741.

Mason, M. C., Giles, G. R., Graham, N. G., Clark, C. G., and Goligher, J. C. (1968). British fournal of Surgery, $55,677$.

Sawyers, J. L., Scott, H. W., Edwards, W. H., Schull, H. J., and Law, D. H. (1968). American fournal of Surgery, 115, 165

(1968). American Fournal of Surgery, 115, 165.
Tovey, F. I. (1969). British fournal of Surgery, 56, 281.

Wilkinson, A. R., and Johnston, D. (1972). Paper presented to Surgical Research Society, London Meeting, January 1972

Williams, E. J., and Irvine, W. T. (1966). Lancet, 1, 1053. 